\title{
Viscoelasticity of Quartz and Kaolin Slurries in Seawater: Importance of Magnesium Precipitates
}

\author{
Matías Jeldres ${ }^{1}$, Eder Piceros ${ }^{2}$, Pedro A. Robles ${ }^{3}$, Norman Toro ${ }^{4,5, *}$ and Ricardo I. Jeldres ${ }^{1}$ (D) \\ 1 Departamento de Ingeniería Química y Procesos de Minerales, Facultad de Ingeniería, Universidad de \\ Antofagasta, Antofagasta 1240000, Chile; mjeldresvalenzuela@gmail.com (M.J.); \\ ricardo.jeldres@uantof.cl (R.I.J.) \\ 2 Faculty of Engineering and Architecture, Universidad Arturo Pratt, P.O. Box 121, Iquique 1100000, Chile; \\ edpicero@unap.cl \\ 3 Escuela de Ingeniería Química, Pontificia Universidad Católica de Valparaíso, Valparaíso 2340000, Chile; \\ pedro.robles@pucv.cl \\ 4 Departamento de Ingeniería Metalúrgica y Minas, Universidad Católica del Norte, Antofagasta 1270709, \\ Chile \\ 5 Department of Mining, Geological and Cartographic Department, Universidad Politécnica de Cartagena, \\ 30202 Murcia, Spain \\ * Correspondence: ntoro@ucn.cl; Tel.: +56-552-651-021
}

Received: 14 September 2019; Accepted: 17 October 2019; Published: 19 October 2019

check for updates

\begin{abstract}
In this study, the viscoelastic properties of quartz and kaolin suspensions in seawater were analysed considering two distinct conditions: $\mathrm{pH} 8$ and 10.7. Creep and oscillatory sweep tests provided the rheological parameters. An Anton Paar MCR 102 rheometer (ANAMIN Group, Santiago, Chile) was used with a vane-in-cup configuration, and the data were processed with RheoCompass ${ }^{\mathrm{TM}}$ Light software (ANAMIN Group, Santiago, Chile). The outcomes were associated with the formation of solid species principally composed of magnesium precipitates. The magnesium in solution reduced in the presence of quartz (68 wt \%), from 1380 to $1280 \mathrm{mg} / \mathrm{L}$. Since the difference was not large regarding the solid-free seawater, the disposition of solid complexes at $\mathrm{pH} 10.7$ was expected to be similar. The jump in $\mathrm{pH}$ caused both yield stress and viscoelastic moduli to drop, suggesting that the solid precipitates diminished the strength of the particle networks that made up the suspension. For the kaolin slurries (37 wt \%), the yield stress raised when the $\mathrm{pH}$ increased, but unlike quartz, there was significant adsorption of magnesium cations. In fact, the concentration of magnesium in solution fell from 1380 to $658 \mathrm{mg} / \mathrm{L}$. Dynamic oscillatory assays revealed structural changes in both pulps; in particular, the phase angle was greater at $\mathrm{pH} 8$ than at $\mathrm{pH} 10.7$, which indicates that at more alkaline conditions, the suspension exhibits a more solid-like character.
\end{abstract}

Keywords: viscoelasticity; quartz; kaolin; seawater; magnesium precipitates

\section{Introduction}

Diverse mining companies have their deposits in arid areas, especially in northern Chile, southern Peru, Australia, Africa and Asia [1,2]. In these regions, water availability may be a serious challenge and is the primary purpose for plants to reduce their water demand while avoiding significant alterations in production. A current strategy implemented in several plants is the use of seawater (see Table 1), either through prior desalination treatment by reverse osmosis, where all salts are eliminated, or by simply applying it directly, without altering the salinity [3-5]. The direct use of seawater entails advantages associated with environmental impact and operational costs that involve the building of a desalination plant [6]; however, the complexity of such an undertaking is the subject of constant discussion and research for engineers and scientists [3]. For example, there is the issue of the location of 
plants that are far from the coast and at a high altitude. This may require a great amount of investment in pumping, but it is the only option in some cases. In this scenario, the efficient use of hydric resources is inevitable, which means advancing effective closures of seawater circuits. Here, it is essential to acquire a deep rheological understanding of the mineral slurries, which restrict performance at the dewatering stages [7].

Table 1. Examples of seawater use in mining (adapted from Cisternas and Gálvez [3]).

\begin{tabular}{cccc}
\hline Plant & Country & Metal & Technology \\
\hline El Boleo Proyect & Mexico & Copper, cobalt, zinc, manganese & Leaching \\
Mount Keith $\left(^{*}\right)$ & Australia & Nickel & Flotation \\
Sierra Gorda SCM & Chile & Copper, molybdenum & Flotation, leaching \\
Black Angel & Greenland & Lead-zinc & Flotation \\
Batu Hijau & Indonesia & Copper-gold & Flotation \\
Beverly Uranium Mine $\left(^{*}\right)$ & Australia & Uranium & Leaching in situ \\
Minera Michilla & Chile & Copper & Leaching \\
Antucoya Proyect & Chile & Copper & Leaching \\
Minera Las Luces & Chile & Copper & Flotation \\
Minera Algorta Norte S.A. & Chile & Iodine & Leaching \\
\hline
\end{tabular}

* Saline water.

The high concentration of electrolytes in solution can hinder distinct stages of mineral processing, such as flotation and tailings management [8,9]. Ions alter the interactions between the particles that constitute the slurries, as well as the behaviour of several reagents which are commonly employed in solid-liquid separation. Consequently, the industry is being driven to implement new methods or technologies that can adapt to the challenges posed by a highly saline environment such as seawater [10,11].

Understanding the fundamentals that govern the rheology of mineral pulps requires an in-depth knowledge of the surface interactions that rule the stability of colloidal systems. It is generally considered that the total interaction energy corresponds to the addition of van der Waals forces with the electric double-layer forces. This is the origin of the classical Derjaguin-Landau-Vervey-Overbeek (DLVO) theory. However, additional interactions may arise in highly saline media that are induced by the solvation of ions and structural changes in the association of water molecules that interact with mineral surfaces such as metal oxides [12]. An essential issue for solvation phenomena is the type of ions dissolved in the solution, wherein maker ions such as $\mathrm{Na}^{+}, \mathrm{Mg}^{2+}$ and $\mathrm{Ca}^{2+}$ are small in size and generate a strong electric field that causes the surrounding water molecules to become highly structured. Otherwise, breaker ions such as $\mathrm{K}^{+}$and $\mathrm{Cl}^{-}$are larger than the maker ions and, therefore, produce a smaller electric field on their neighbouring molecules, disorganising the layers of associated water molecules around the ions [13-15].

Copper concentration operations in freshwater are normally carried out under highly alkaline conditions (above $\mathrm{pH}$ 10.5) to depress pyrite and prevent contamination of the concentrate [16-18]; however, it is challenging to operate in seawater at this condition and, generally, the processes are restricted to the natural $\mathrm{pH}$ (approx. $\mathrm{pH} 8$ ), requiring further reagents to deal with the quality of concentrates [5,19]. At a high $\mathrm{pH}$, the seawater divalent cations $\left(\mathrm{Mg}^{2+}\right.$ and $\left.\mathrm{Ca}^{2+}\right)$ can hydrolyse to form soluble complexes (e.g., $\mathrm{Mg}(\mathrm{OH})^{+}$and $\mathrm{Ca}(\mathrm{OH})^{+}$) and varied solid substances (e.g., $\mathrm{Mg}(\mathrm{OH})_{2}, \mathrm{Ca}(\mathrm{OH})_{2}$, etc.). These species may adsorb onto the mineral's surface, which includes the main component of copper tailings such as kaolin and silica. Some reports indicate that the presence of complexes reduces the magnitude of the anionic zeta potential of particles, while solid precipitates can even assign them cationic values [20]. This leads to a substantial impact on the interaction between particles, and consequently, the effect on the rheological properties can be remarkable [21,22].

The tailings produced in copper processing operations mainly contain a significant amount of clays and quartz, which are consistently the focus of study since these determine the rheological 
behaviour of the tailings [23]. Teh et al. [24] analysed the yield stress and zeta potential at different $\mathrm{pH}$ levels in kaolin pulps. The results confirmed that, in most cases, the yield-stress-DLVO model is obeyed, which means that the highest yield stress occurs at low magnitudes of zeta potential. Kaolinite, the molecular formula of which is $\left[\mathrm{Al}_{4}\left(\mathrm{Si}_{4} \mathrm{O}_{10}\right)(\mathrm{OH})_{8}\right]$, has three crystallographically different surfaces: a silica face, an alumina face and the edges. Previous studies revealed that, at a low $\mathrm{pH}$, the alumina face and the edges have cationic charges, while the silica face is anionic. This promotes the formation of strong bonds between particles and, consequently, high yield stress. However, at a high $\mathrm{pH}$, the faces and edges have anionic charges, which causes the dispersion of the particles and thus leads to lower yield stress [25]. Avadiar et al. [26] studied the rheological behaviour of alumina, silica and kaolin slurries in the presence of calcium and magnesium salts. It was detected that the adsorption of $\mathrm{Ca}(\mathrm{OH})^{+}$and the precipitation of $\mathrm{Ca}(\mathrm{OH})_{2}$ induced a stronger association of particles than that caused by adsorption of $\mathrm{Mg}(\mathrm{OH})^{+}$and solids of $\mathrm{Mg}(\mathrm{OH})_{2}$. The authors ascribed this to the larger size of the calcium complexes and precipitates, and due to hydration/solvation phenomena, these possess a lower enthalpy of hydration than $\mathrm{Mg}(\mathrm{OH})^{+}$and $\mathrm{Mg}(\mathrm{OH})_{2}$, respectively. Therefore, the former should adsorb more readily on the particles' surface [27].

The yield stress is the most used rheological parameter to characterise the flow properties of mining tailings, indicating the stress that must be overcome by the pulps so that they begin to flow [28-30]. However, extending to a better rheological characterisation can provide more insight into the strength of the particle networks that make up the suspensions, giving further control opportunities in tailings handling, especially in the discharge of the underflow by rakes in thickeners. In this case, mineral pulps can exhibit viscoelastic behaviours, which are described by a viscous component, represented by the storage modulus $\left(G^{\prime}\right)$, and an elastic part, represented by the loss modulus $\left(G^{\prime \prime}\right)$ [31]. The viscoelastic modulus can be obtained by means of dynamic methods of oscillatory rheology, which are carried out by subjecting the material to an oscillatory strain $\gamma(t)=\gamma_{0} \sin (\omega t)$, where the resulting stress in relation to time is $\tau(t)=\gamma_{0}\left(G^{\prime}(\omega) \sin (\omega t)+G^{\prime \prime}(\omega) \cos (\omega t)\right)$, where $G^{\prime}$ is a measure of the stored energy of the material and, therefore, is related to molecular events of an elastic nature, while $G^{\prime \prime}$ is a measure of energy dissipated as heat, associated with molecular events of a viscous character [32]. Additionally, creep tests consist of applying permanent stress to a specific material, measuring the temporal evolution of its shear strain. The tests can be used as a descriptor of the strength of the particle networks since stronger structures deform less [33,34]. Jeldres et al. [15] studied the effect of the type of salt on the viscoelastic behaviour of silica suspensions prepared in monovalent brines. By increasing the size of the cations, higher values of yield stress, elastic modulus and complex viscosity were obtained, while the shear strain after application of fixed stress was lower. The authors explained that silica has a greater tendency to agglomerate in the presence of larger ions such as $\mathrm{K}^{+}$, forming stronger particle networks compared with smaller salts such as $\mathrm{Na}^{+}$and $\mathrm{Li}^{+}$.

Several studies have analysed rheological behaviour in saline media, with respect to the primary minerals that compose mining tailings, such as quartz and clays. The reported investigations covered interpretation in monovalent $[15,35,36]$ and divalent salt solutions $[26,37]$. However, no systematic study has explained the viscoelastic behaviour of these minerals in seawater, especially at a high $\mathrm{pH}(\mathrm{pH}>10.5)$, where interference by complexes of calcium and magnesium may appear. These conditions are potentially attractive to carry out the concentration stages, particularly in the copper industry, when the ores have a high content of pyrite [38]. In this sense, the objective of this study was to examine the influence of the principal ionic species present in seawater on the viscoelastic behaviour of quartz and kaolin slurries. The varied $\mathrm{pH}$ levels were linked to the formation of soluble complexes and solid precipitates of divalent cations, and their remarkable impact on rheological properties were studied through creep and oscillatory rheology tests. 


\section{Methodology}

\subsection{Materials}

Kaolin was acquired from Ward's Science, and quantitative X-ray diffraction (XRD) analysis showed that it contained $84 \mathrm{wt} \%$ kaolinite $\left(\mathrm{Al}_{2} \mathrm{Si}_{2} \mathrm{O}_{5}(\mathrm{OH})_{4}\right)$ and $16 \mathrm{wt} \%$ halloysite $\left(\mathrm{Al}_{2} \mathrm{Si}_{2} \mathrm{O}_{5}(\mathrm{OH})_{4} \cdot 2 \mathrm{H}_{2} \mathrm{O}\right)$ (Figure 1). A D5000 X-ray diffractometer (Siemens S.A., Lac Condes, Chile) was used and the data were processed with Total Pattern Analysis Software (TOPAS) (Siemens S.A., Lac Condes, Chile). The FTIR spectrum (Figure 2) showed a double peak at 3696 and $3654 \mathrm{~cm}^{-1}$, characteristic of the kaolin group. Three absorption bands at 3696,3654 and $3621 \mathrm{~cm}^{-1}$ reflected the high structural order of the samples by the $\mathrm{OH}$ stretching of the inner-surface hydroxyl groups. There was Si-O stretching at 1115 , 1032 and $1009 \mathrm{~cm}^{-1}$. Al-O-Si deformation appeared at $539 \mathrm{~cm}^{-1}$, Si-O-Si deformation appeared at $471 \mathrm{~cm}^{-1}$ and $\mathrm{Si}-\mathrm{O}$ deformation appeared at $431 \mathrm{~cm}^{-1}$. The zeta potential at $\mathrm{pH} 8$ in distilled water was $-40 \mathrm{mV}$. This was measured using a Zetameter System 4.0 (Zeta-meter, Staunton, VA, USA) following the methodology of Jeldres et al. [15].

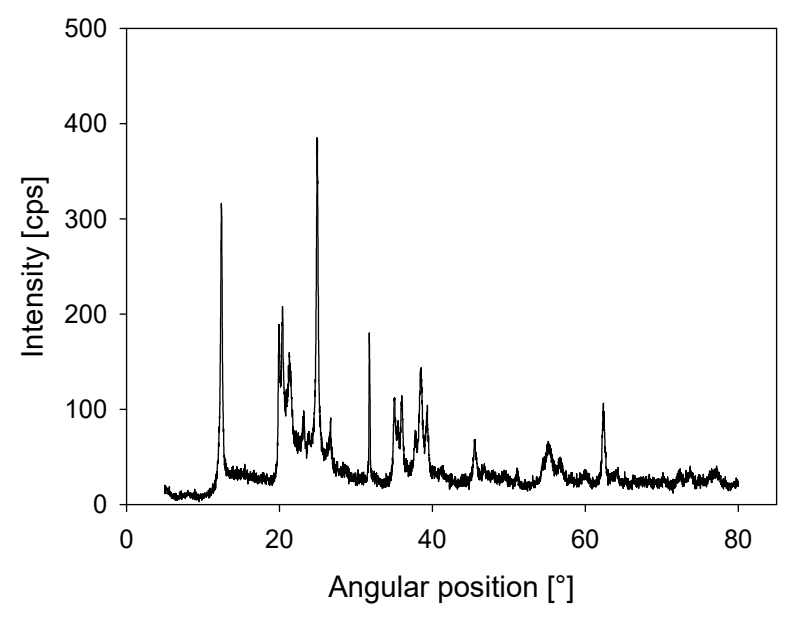

Figure 1. X-ray diffraction (XRD) for kaolin powder.

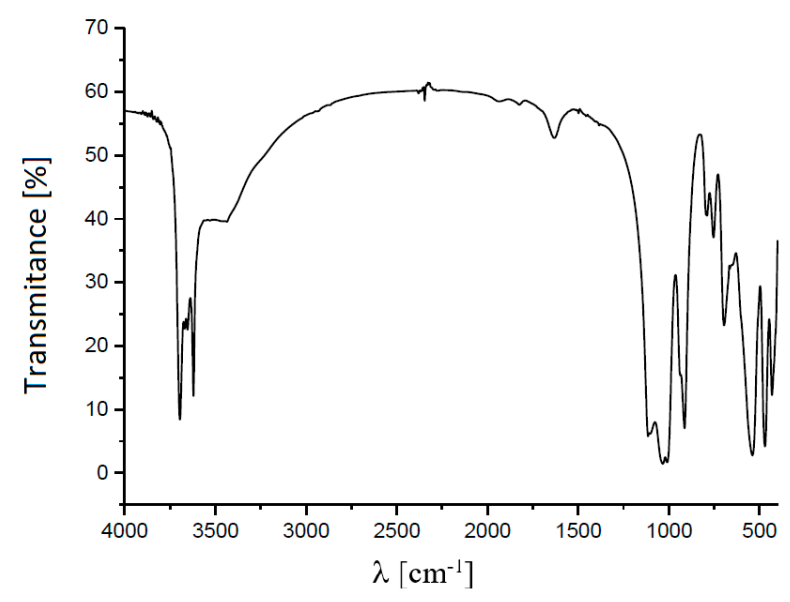

Figure 2. Fourier Transform Infrared Spectroscopy (FTIR) spectrum for kaolin powder.

Quartz was acquired from a local Chilean store, where the $\mathrm{SiO}_{2}$ content detected by quantitative XRD was over 99 wt \% (see Figure 3) and the zeta potential in distilled water at $\mathrm{pH} 8 \mathrm{was}-45 \mathrm{mV}$. 


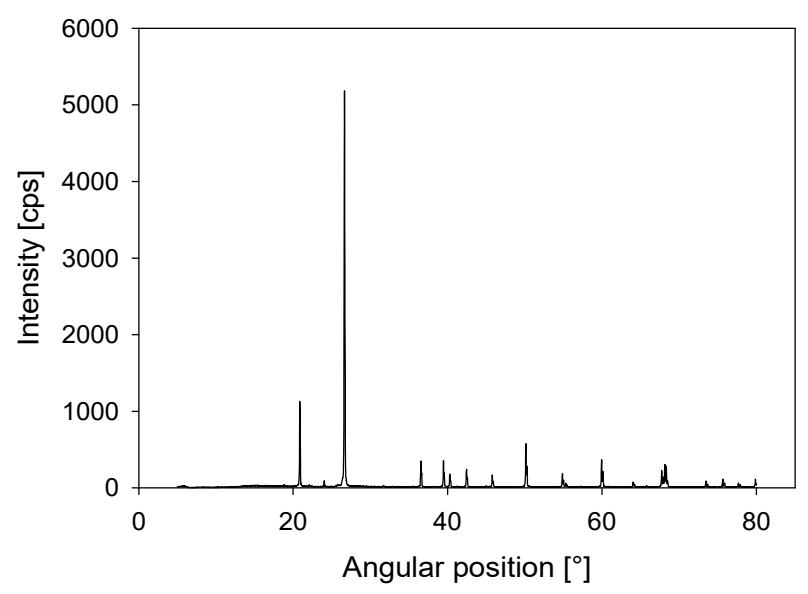

Figure 3. X-ray diffraction (XRD) for quartz powder.

The volume weighted particle size distribution (PSD) was obtained using a Microtrac S3500 laser diffraction particle size analyser (Verder Scientific, Newtown, PA, USA). The PSD of the quartz and kaolin samples are shown in Figure 4, where it was found that $10 \%$ of the particles were smaller than $d_{10}=1.8$ and $3.8 \mu \mathrm{m}$ in the samples of kaolin and quartz, respectively.

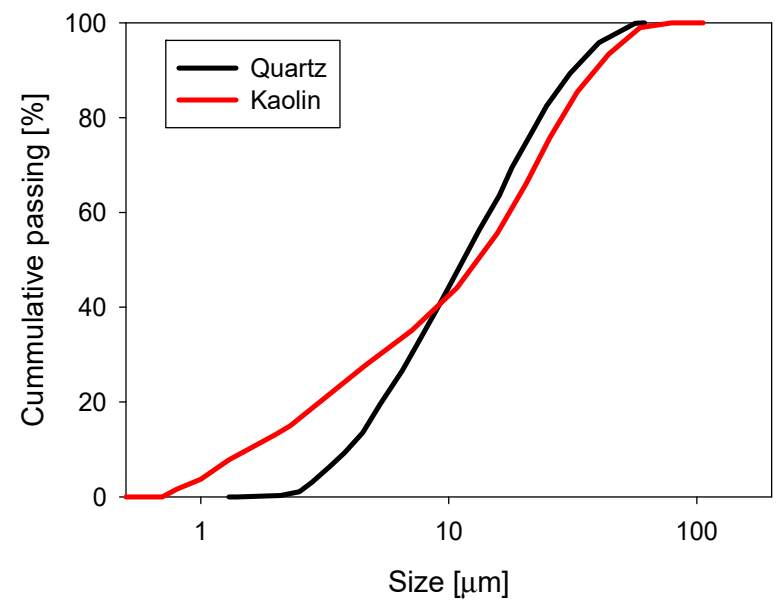

Figure 4. Particle size distribution for quartz and kaolin in distilled water at natural $\mathrm{pH}$.

Seawater was obtained from the San Jorge Bay in Antofagasta, Chile. The water was filtered at $1 \mu \mathrm{m}$ using a UV filter system to eliminate the bacterial activity. The cation concentrations were determined by atomic absorption spectrophotometry: $\mathrm{Na}^{+}: 10.9 \mathrm{~g} / \mathrm{L} ; \mathrm{Mg}^{2+}: 1.38 \mathrm{~g} / \mathrm{L}^{2} \mathrm{Ca}^{2+}: 0.4 \mathrm{~g} / \mathrm{L} ; \mathrm{K}^{+}$: $0.39 \mathrm{~g} / \mathrm{L}$. By the argentometric method, $\mathrm{Cl}^{-}$was found to be $19.6 \mathrm{~g} / \mathrm{L}$. By acid-base volumetry, $\mathrm{HCO}^{3-}$ was found to be $0.15 \mathrm{mg} / \mathrm{L}$. The conductivity was $50.4 \mathrm{mS} / \mathrm{cm}$ at $25^{\circ} \mathrm{C}$ and natural $\mathrm{pH}$.

The $\mathrm{pH}$ was raised with sodium hydroxide $(\mathrm{NaOH})$ of analytical grade (over $98 \%$ ), with the presence of sodium carbonate less than $0.5 \%$. The pulps were mixed with a mechanical stirrer, and the reagent was added gradually. The $\mathrm{pH}$ was recorded with a PHS-3BW $\mathrm{pH}$ meter (Bante Instrument, Shanghai, China).

\subsection{Rheology}

Stock slurries of silica and kaolin were prepared at 68 and $37 \mathrm{wt} \%$, respectively, by mixing the solid with seawater overnight with magnetic stirring. The $\mathrm{pH}$ was adjusted with sodium hydroxide either to $\mathrm{pH} 8$ or 10.7. Once prepared, a $60 \mathrm{~mL}$ aliquot was extracted to perform the rheological assays, while the remaining pulp continued under mixing. Each aliquot was used for a single rheological test and then discarded. 
The experiments were carried out on an Anton Paar MCR 102 rheometer, and the data were processed with Rheocompass software. A vane-in-cup configuration was used to minimise the wall-slip effects. The diameter of the vane was $2.2 \mathrm{~cm}$ and that of the cup was $4.2 \mathrm{~cm}$.

Creep tests were performed by applying constant stress for $1200 \mathrm{~s}$, which generated an increase in the strain angle $(\theta)$ as a function of time. Then, the shear strain $(\gamma)$ was obtained by Equation (1), considering that the material has linear viscoelastic behaviour:

$$
\gamma=\frac{2 \theta}{\left(1-\left(d_{v} / d_{c}\right)^{2}\right)}
$$

where $\theta$ is the strain angle, $d_{v}$ is the vane diameter and $d_{c}$ is the cup diameter. The apparent compliance $(J)$ is the apparent shear strain divided by the applied shear stress as follows:

$$
J=\frac{\gamma}{\tau_{\text {creep }}} .
$$

If $J$ remains constant concerning the applied stress, the slurry exhibits a linear viscoelastic behaviour; otherwise, it is a nonlinear viscoelastic material. Equation (1) is valid only for linear viscoelastic materials, but errors due to nonlinear viscoelasticity are expected to be small because the main interest of this study was to capture only the trend of transition behaviour. The yield stress was determined as the average between the stress that causes a maximum strain (critical strain) and the minimum stress necessary for the pulp to start flowing instantly.

The oscillatory tests were carried out for a frequency sweep between 0.1 and $100 \mathrm{rad} / \mathrm{s}$, keeping the shear strain at $0.5 \%$, previously selected by a sweep amplitude. This ensured that the test was performed in the linear viscoelastic regime, wherein the deformation is proportional to the applied stress, and the viscoelastic moduli have physical meaning.

\section{Results}

This section analyses the viscoelastic behaviour of silica and kaolin suspensions in seawater, using the results of the creep and oscillatory sweeps tests. Different rheological parameters were obtained, such as apparent critical strain, yield stress, viscoelastic modulus and phase angle. These parameters were associated with the variations of $\mathrm{pH}$ and the appearance of magnesium precipitates, which are made in seawater at alkaline conditions, and were distinguished by speciation graphs and the consumption of sodium hydroxide.

\subsection{Formation of Magnesium Precipitates}

The principal chemical reactions that make soluble magnesium complexes and solid precipitates in seawater are the following:

$$
\begin{gathered}
\mathrm{CO}_{2(\mathrm{~g})}+\mathrm{H}_{2} \mathrm{O}_{(\mathrm{l})} \leftrightarrow \mathrm{H}_{2} \mathrm{CO}_{3} \\
\mathrm{H}_{2} \mathrm{CO}_{3} \leftrightarrow \mathrm{HCO}_{3}^{-}+\mathrm{H}^{+} \\
\mathrm{HCO}_{3}^{-} \leftrightarrow \mathrm{CO}_{3}^{2-}+\mathrm{H}^{+} \\
\mathrm{Mg}^{2+}+\mathrm{HCO}_{3}^{-} \leftrightarrow \mathrm{MgHCO}_{3}^{+} \\
\mathrm{Mg}^{2+}+\mathrm{OH}^{-} \leftrightarrow \mathrm{MgOH}^{+} \\
\mathrm{Mg}^{2+}+\mathrm{CO}_{3}^{2-} \leftrightarrow \mathrm{MgCO}_{3} \\
\mathrm{Mg}^{2+}+2 \mathrm{OH}^{-} \leftrightarrow \mathrm{Mg}(\mathrm{OH})_{2}
\end{gathered}
$$

The formation of magnesium precipitates and complexes generates a buffer effect, which can be identified in a range where a high amount of reagent is required to raise the $\mathrm{pH}$ slightly. Nevertheless, 
the presence of particles (concentrated slurries) interferes with the concentration of ions dissolved in solution, modifying precipitation reactions and the buffer effect. Indeed, a chemical analysis by Atomic Absorption Spectroscopy (AAS) determined that the magnesium in seawater reduced from 1380 to $1280 \mathrm{mg} / \mathrm{L}$ in the quartz pulps, while it dropped from 1380 to $658 \mathrm{mg} / \mathrm{L}$ in the kaolin suspension.

The amount of sodium hydroxide used $(\mathrm{g} / \mathrm{L})$ to raise the $\mathrm{pH}$ of seawater, quartz pulp and kaolin pulp, normalised by the amount required to obtain $\mathrm{pH}$ 12.2, is shown in Figure 5. A marked buffer effect was observed for pure seawater and quartz slurry between $\mathrm{pH} 10$ and 11, which coincided with the formation of magnesium precipitates, where carbonate precipitation started at $\mathrm{pH} 9.3$ and ended at $\mathrm{pH}$ 10, while hydroxide deposition started at $\mathrm{pH} 10.3$ and completed at $\mathrm{pH} 11$ [39-41]. This effect was not clear in the kaolin pulp, indicating a lower formation of magnesium precipitates, which is compatible with the loss of magnesium in solution (from 1380 to $659 \mathrm{mg} / \mathrm{L}$ ). Considering the low cationic exchange capacity of kaolinite $[42,43]$, it is expected that magnesium cations are attached to the anionic sites of the clay's surface by electrostatic attraction. The adsorption of magnesium ions reduces its concentration in solution, reducing the formation of solid complexes at a high $\mathrm{pH}$.

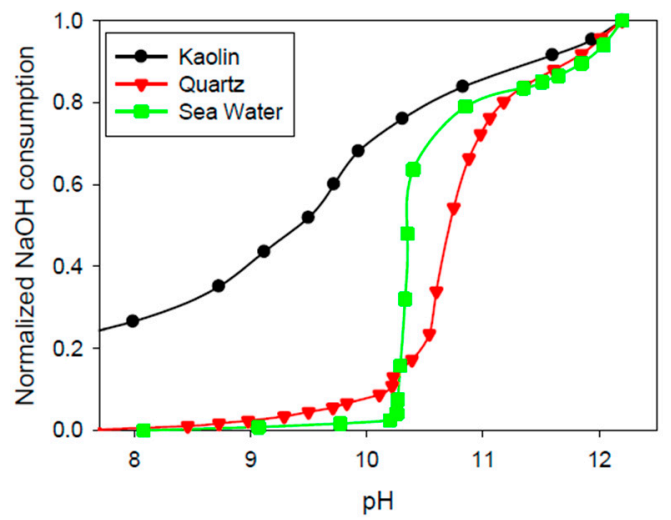

Figure 5. Sodium hydroxide $(\mathrm{NaOH})$ required to modify the $\mathrm{pH}$ of (i) seawater, (ii) quartz slurry in seawater and (iii) kaolin slurry in seawater. $\mathrm{NaOH}$ is mass $(\mathrm{g})$ consumed per $1 \mathrm{~L}$ of solution, normalised by the concentration at $\mathrm{pH} 12.2$ (seawater: $6.1 \mathrm{~g} / \mathrm{L}$; quartz: $5.7 \mathrm{~g} / \mathrm{L}$; kaolin: $9.1 \mathrm{~g} / \mathrm{L}$ ).

\subsection{Creep Tests}

Figure 6a-d display the creep tests for quartz and kaolin slurries prepared with seawater at $\mathrm{pH} 8$ and 10.7. The temporal evolution of the apparent strain was measured under fixed stress for $1200 \mathrm{~s}$, and in all cases, a maximum strain was observed that remained constant at high times. When the applied stress was greater than a critical value, the pulp started to flow, and its deformation diverged. An apparent instantaneous strain was observed for the quartz pulps when the stress was lower than half of the yield stress (Figure 6a,b). This effect was not observed for kaolin pulps, which exhibited a gradual increase in their apparent strains (Figure 6c,d).

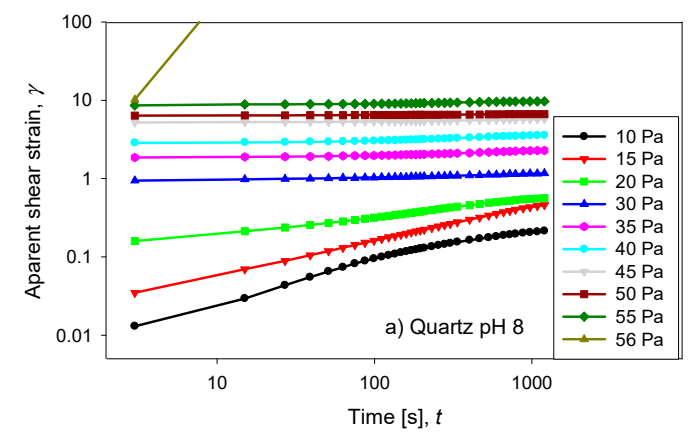

(a)

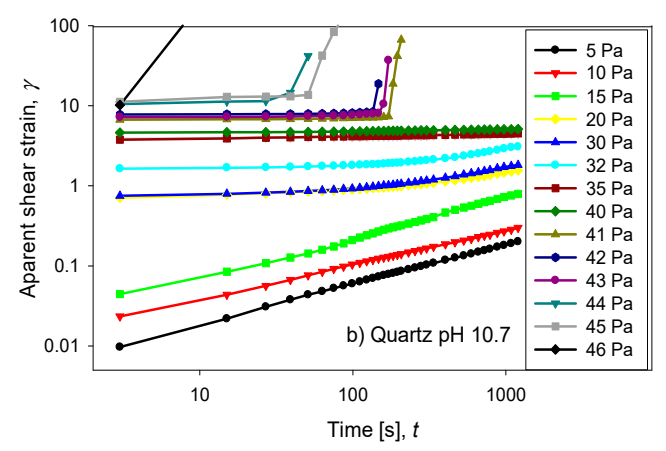

(b)

Figure 6. Cont. 


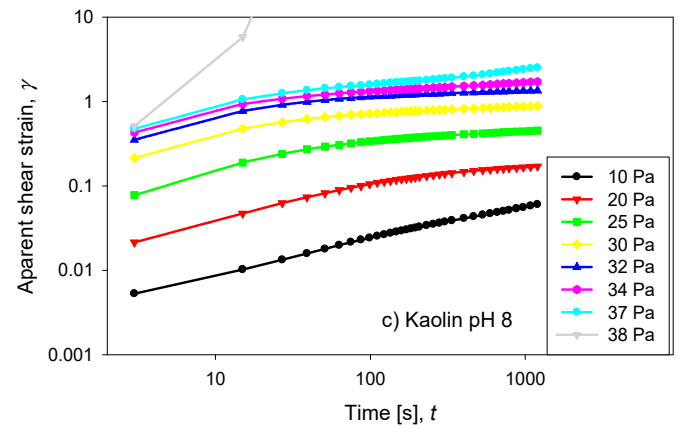

(c)

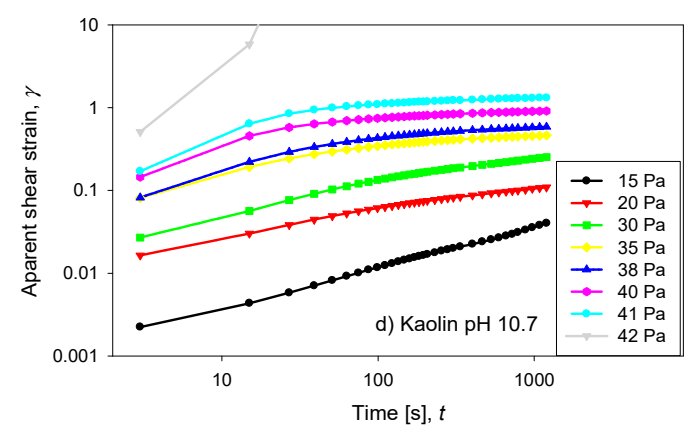

(d)

Figure 6. Creep test for quartz and kaolin slurries at varied applied stresses: (a) quartz at $\mathrm{pH}$, (b) quartz at $\mathrm{pH} 10.7$, (c) kaolin at $\mathrm{pH} 8$ and (d) kaolin at $\mathrm{pH} 10.7$.

The yield stress for each pulp examined in this study is shown in Figure 7. The quartz slurry at $\mathrm{pH} 8$ reached a yield stress of $56 \mathrm{~Pa}$, which was significantly higher than the $43 \mathrm{~Pa}$ obtained at $\mathrm{pH}$ 10.7. Interestingly, the decrease of yield stress by increasing the $\mathrm{pH}$ (from $\mathrm{pH} 8$ to 10.7) coincided with the formation of solid complexes in seawater. In the literature, it has been reported that these products can adsorb onto the surface of the particles, having different consequences on the rheological properties [22]. The solid complexes may form bonds between quartz particles, mainly due to the reduction of zeta potential [20], but the strength of these bonds would be weaker compared with the cationic bridges generated by the divalent $\mathrm{Mg}^{2+}$ ions. For this reason, it is expected that at $\mathrm{pH}$ 8 , where the concentration of $\mathrm{Mg}^{2+}$ ions in solution is higher, the yield stress is higher. On the other hand, the kaolin suspension at $\mathrm{pH} 8$ had a yield stress of $38 \mathrm{~Pa}$, while at $\mathrm{pH} 10.7$, it increased to $42 \mathrm{~Pa}$. This behaviour is contrary to the quartz pulp and can be justified by the low presence of solid precipitates.

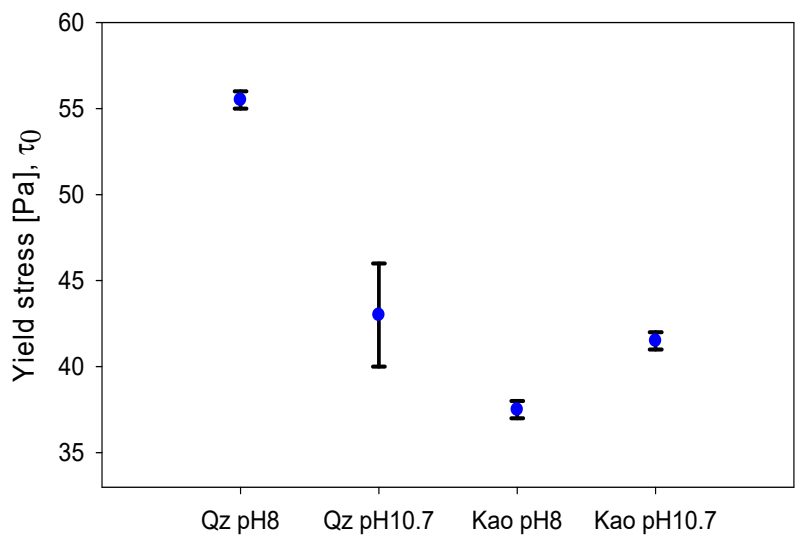

Figure 7. Yield stress for quartz and kaolin slurries at different $\mathrm{pH}$ levels.

Critical shear strain is an attractive property of materials, which is directly associated with the strength of the bonds that form the particle networks just before they begin to flow [44]. Figure 8 shows the critical strain, where for both minerals, the shear strain decreased as there was an increase in $\mathrm{pH}$. 


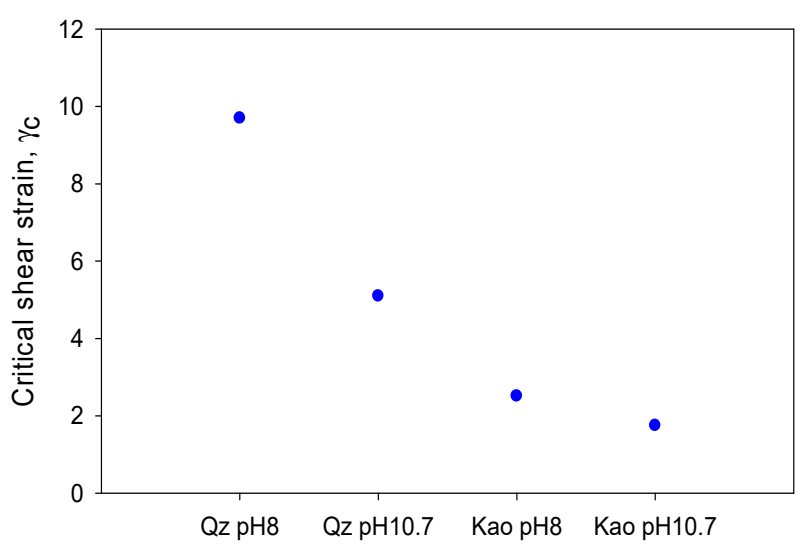

Figure 8. Critical shear strain for quartz and kaolin slurries at different $\mathrm{pH}$ levels.

An exceptional contrast of the system that held precipitates (quartz at $\mathrm{pH}$ 10.7) with respect to the rest of the slurries is that the yield stress was displayed in a range of stress (40-46 Pa) instead of a single point. For that matter, the pulp began to flow depending on both the applied stress and the time of stress application (Figure 9). Otherwise, for pulps in which there were no solid precipitates, the yield stress was a precise value: quartz pH 8, $55 \mathrm{~Pa}$; kaolin $\mathrm{pH} 8,38 \mathrm{~Pa}$; and kaolin $\mathrm{pH}$ 10.7, $42 \mathrm{~Pa}$.

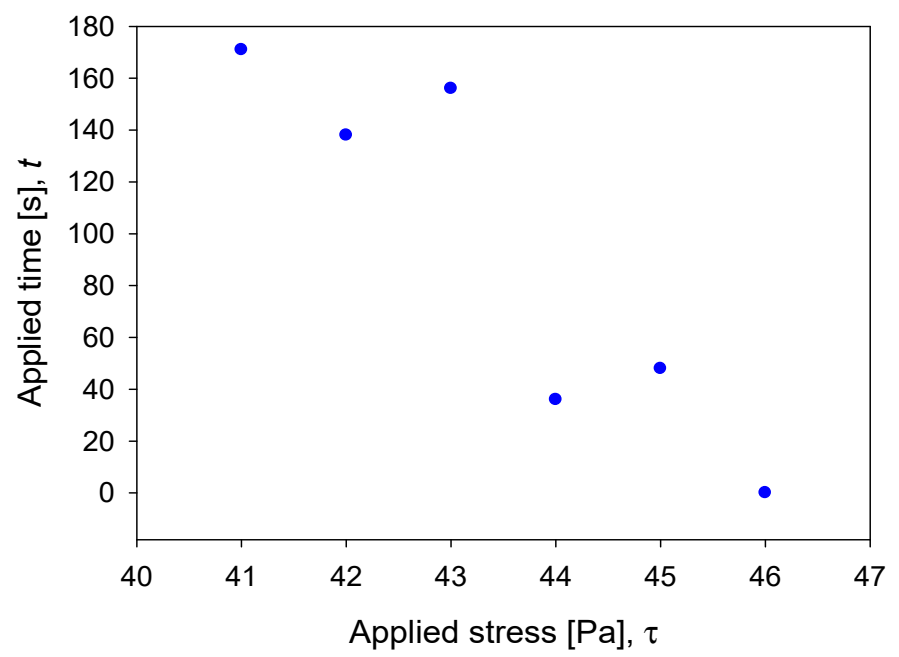

Figure 9. Relationship between yield stress and applied time for quartz slurries at $\mathrm{pH}$ 10.7.

Mineral pulps may exhibit linear or nonlinear viscoelastic behaviour, or both, depending on the applied stress. A linear response implies that compliance remains constant, independent of the stress which was employed. This characteristic is shown in Figure 10, considering the compliance at the end of the experiment (1200 s). The kaolin pulp at $\mathrm{pH} 8$ suggested linear viscoelastic behaviour when the stress was lower than $20 \mathrm{~Pa}$, while at $\mathrm{pH} 10.7$, the linear response limit was up to the stress of $35 \mathrm{~Pa}$. On the other hand, the quartz slurry at $\mathrm{pH} 8 \mathrm{had}$ a linear behaviour up to $30 \mathrm{~Pa}$, while at $\mathrm{pH} 10.7$, the system of which was affected by the presence of complexes and solid precipitates, the linearity decreased considerably to a stress lower than $10 \mathrm{~Pa}$. 


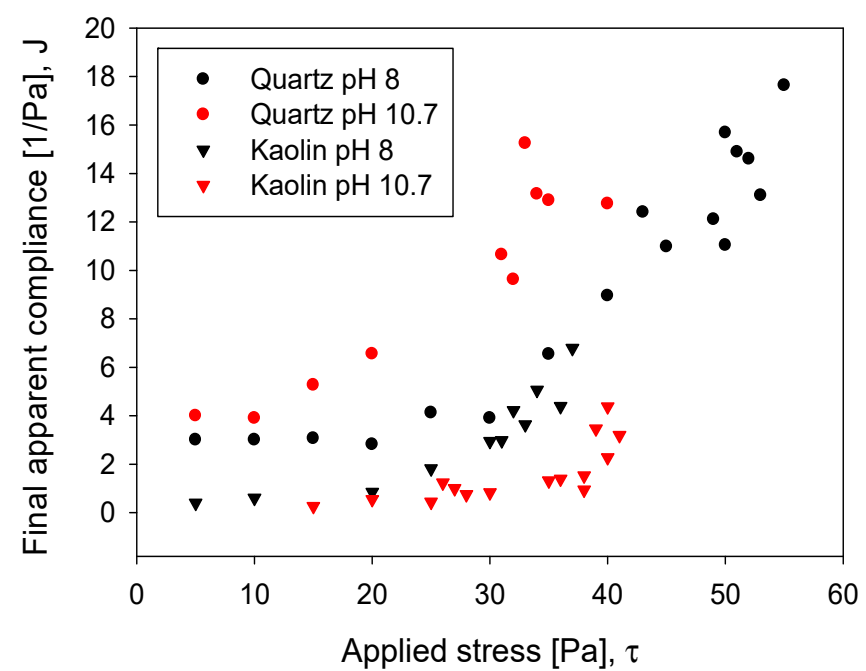

Figure 10. Final apparent compliance as a function of stress for quartz and kaolin slurries.

\subsection{Oscillatory Rheology}

Oscillatory rheology tests are a good descriptor of pulp strength. In this case, a frequency sweep was performed considering a constant amplitude of $0.5 \%$, previously defined by an amplitude sweep test. This ensured that the pulp was in a linear viscoelastic regime. Figure 11 shows the response of both moduli $G^{\prime}$ and $G^{\prime \prime}$ concerning the angular frequency for the silica suspension. Viscoelastic moduli had a higher value when silica was at $\mathrm{pH} 8$, meaning a greater resistance of the particle networks, while at $\mathrm{pH}$ 10.7, both moduli were diminished. Interestingly, for both $\mathrm{pH}$ levels, the moduli $G^{\prime}$ and $G^{\prime \prime}$ crossed within the range of frequencies examined. The crossover point was an indicator of the relaxation time, using the reciprocal of frequency under conditions where both moduli intersected. While at pH 8 the relaxation time was $8.6 \mathrm{~s}$, at $\mathrm{pH} 10.7$, the value increased to $10.8 \mathrm{~s}$. For the kaolin pulps, the behaviour was different (Figure 12), and for both $\mathrm{pH}$ values (8 and 10.7), the storage modulus ( $\left.G^{\prime}\right)$ was higher than the loss modulus $\left(G^{\prime \prime}\right)$. It can be argued that both moduli had a weak dependence on frequency, which is a typical gel behaviour [32]. The phase angle, as shown in Figure 13, was higher at pH 8 than at $\mathrm{pH}$ 10.7, for both minerals. This suggests that the $\mathrm{pH}$ changed the internal structure of the pulps, adopting a more solid-like character when the $\mathrm{pH}$ was more alkaline. In the silica suspension, it was observed that at frequencies greater than $30 \mathrm{rad} / \mathrm{s}$, the phase angle was independent of the applied frequency, while for kaolin pulp, this happened at over $10 \mathrm{rad} / \mathrm{s}$.

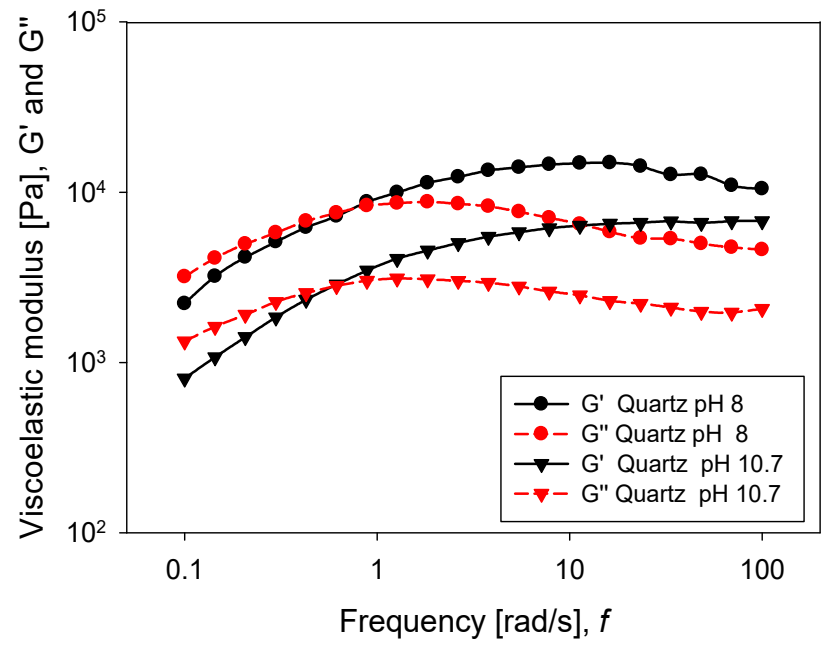

Figure 11. Frequency sweep for quartz slurries at different $\mathrm{pH}$ levels. 


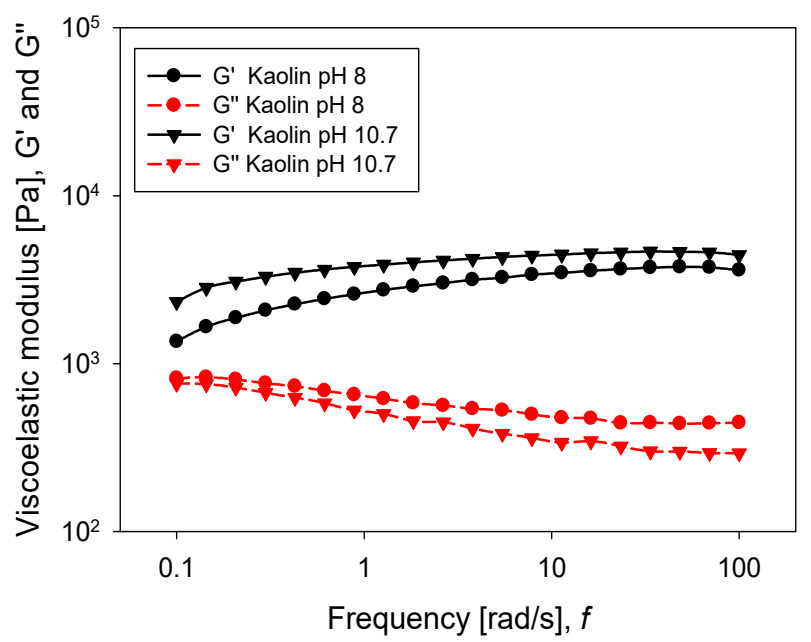

Figure 12. Frequency sweep for kaolin slurries at different $\mathrm{pH}$ levels.

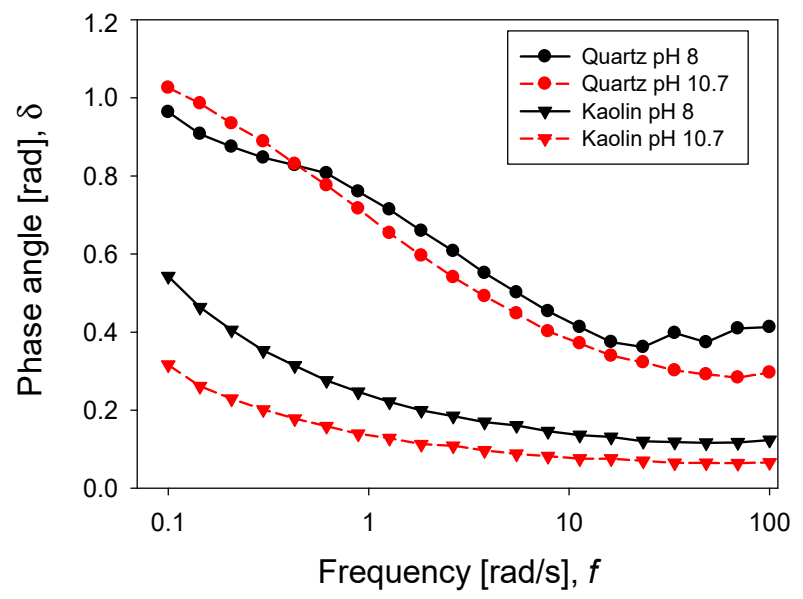

Figure 13. Phase angle for quartz and kaolin slurries at varied $\mathrm{pH}$ levels.

\section{Conclusions}

The viscoelastic properties of quartz and kaolin suspensions in seawater were analysed, examining two different conditions: (i) $\mathrm{pH} \mathrm{8,} \mathrm{which} \mathrm{resembles} \mathrm{that} \mathrm{used} \mathrm{by} \mathrm{copper} \mathrm{concentrating} \mathrm{plants,} \mathrm{and}$ (ii) $\mathrm{pH} 10.7$, which is attractive since it may enhance the quality of concentrates. Nevertheless, the latter is characterised by speciation reactions of divalent seawater cations, which lead to the formation of solid precipitates, mainly magnesium complexes. This feature changes for slurries according to the mineral species because the particles' surfaces can adsorb a portion of the cations, reducing their content in solution. Here, quartz pulp reduced magnesium from 1380 to $1280 \mathrm{mg} / \mathrm{L}$. Since it was not a large difference from the solid-free seawater, the disposition of solid complexes at $\mathrm{pH} 10.7$ was similar. As rheological consequences, the increase in $\mathrm{pH}$ caused both yield stress and viscoelastic moduli to drop, suggesting that the solid precipitates diminished the strength of the particle networks that made up the suspension. For the kaolin slurries, the yield stress raised when the $\mathrm{pH}$ increased, but unlike quartz, there was significant adsorption of magnesium cations. In fact, the concentration of magnesium in solution fell from 1380 to $658 \mathrm{mg} / \mathrm{L}$.

The dynamic oscillatory assays revealed structural changes for both pulps; in particular, the phase angle was higher at $\mathrm{pH} 8$ than at $\mathrm{pH}$ 10.7, showing that the more alkaline suspension exhibited a more solid-like character.

Author Contributions: All of the authors contributed to analysing the results and writing the paper.

Funding: This research was funded by Conicyt Fondecyt 11171036 and Centro CRHIAM Project Conicyt/Fondap/15130015. 
Acknowledgments: Ricardo I. Jeldres thanks Conicyt Fondecyt 11171036 and Centro CRHIAM Project Conicyt/Fondap/15130015. The authors are grateful for the contribution of the Scientific Equipment Unit-MAINI of the Universidad Católica del Norte for facilitating the XRD analysis. Pedro Robles thanks the Pontificia Universidad Católica de Valparaíso for the support provided.

Conflicts of Interest: The authors declare no conflict of interest.

\section{References}

1. Northey, S.A.; Mudd, G.M.; Werner, T.T.; Jowitt, S.M.; Haque, N.; Yellishetty, M.; Weng, Z. The exposure of global base metal resources to water criticality, scarcity and climate change. Glob. Environ. Chang. 2017, 44, 109-124. [CrossRef]

2. Shao, D.; Li, X.; Gu, W. A method for temporary water scarcity analysis in humid region under droughts condition. Water Resour. Manag. 2015, 29, 3823-3839. [CrossRef]

3. Cisternas, L.A.; Gálvez, E.D. The use of seawater in mining. Miner. Process. Extr. Metall. Rev. 2018, 39, 18-33. [CrossRef]

4. Li, W.; Li, Y.; Wei, Z.; Xiao, Q.; Song, S. Fundamental studies of SHMP in reducing negative effects of divalent ions on molybdenite flotation. Minerals 2018, 8, 404. [CrossRef]

5. Jeldres, R.I.; Forbes, L.; Cisternas, L.A. Effect of seawater on sulfide ore flotation: A review. Miner. Process. Extr. Metall. Rev. 2016, 37, 369-384. [CrossRef]

6. Lattemann, S.; Höpner, T. Environmental impact and impact assessment of seawater desalination. Desalination 2008, 220, 1-15. [CrossRef]

7. McFarlane, A.J.; Bremmell, K.E.; Addai-Mensah, J. Optimising the dewatering behaviour of clay tailings through interfacial chemistry, orthokinetic flocculation and controlled shear. Powder Technol. 2005, 160, 27-34. [CrossRef]

8. Lucay, F.; Cisternas, L.A.; Gálvez, E.D.; López Valdivieso, A. Study of the natural floatability of molybdenite fines in saline solutions and effect of gypsum precipitation. Miner. Metall. Process. 2015, 32, $203-208$. [CrossRef]

9. Ramos, O.; Castro, S.; Laskowski, J.S. Copper-molybdenum ores flotation in sea water: Floatability and frothability. Miner. Eng. 2013, 53, 108-112. [CrossRef]

10. Cruz, C.; Reyes, A.; Jeldres, R.I.; Cisternas, L.A.; Kraslawski, A. Using partial desalination treatment to improve the recovery of copper and molybdenum minerals in the Chilean mining industry. Ind. Eng. Chem. Res. 2019. [CrossRef]

11. Jeldres, R.I.; Arancibia-Bravo, M.P.; Reyes, A.; Aguirre, C.E.; Cortes, L.; Cisternas, L.A. The impact of seawater with calcium and magnesium removal for the flotation of copper-molybdenum sulphide ores. Miner. Eng. 2017, 109, 10-13. [CrossRef]

12. Israelachvili, J. Intermolecular and Surface Forces, 3rd ed.; Elsevier: Santa Barbara, CA, USA, 2011.

13. Hofmeister, F. Zur Lehre von der Wirkung der Salze. Arch. Exp. Pathol. Pharmcol. 1888, 24, $247-260$. [CrossRef]

14. Morag, J.; Dishon, M.; Sivan, U. The governing role of surface hydration in ion specific adsorption to silica: An AFM-based account of the hofmeister universality and its reversal. Langmuir 2013, 29, 6317-6322. [CrossRef] [PubMed]

15. Jeldres, R.I.; Piceros, E.C.; Leiva, W.H.; Toledo, P.G.; Quezada, G.R.; Robles, P.A.; Valenzuela, J. Analysis of silica pulp viscoelasticity in saline media: The effect of cation size. Minerals 2019, 9, 216. [CrossRef]

16. Mu, Y.; Peng, Y.; Lauten, R.A. The depression of pyrite in selective flotation by different reagent systems-A Literature review. Miner. Eng. 2016, 96-97, 143-156. [CrossRef]

17. Jeldres, R.I.; Uribe, L.; Cisternas, L.A.; Gutierrez, L.; Leiva, W.H.; Valenzuela, J. The effect of clay minerals on the process of flotation of copper ores-A critical review. Appl. Clay Sci. 2019, 170, 57-69. [CrossRef]

18. Zanin, M.; Lambert, H.; du Plessis, C.A. Lime use and functionality in sulphide mineral flotation: A review. Miner. Eng. 2019, 143, 105922. [CrossRef]

19. Castro, S. Challenges in flotation of Cu-Mo Sulfide Ores in Sea Water I. In Water in Mineral Processing; Society for Mining, Metallurgy, and Exploration: Englewoog, NJ, USA, 2012; pp. 29-40.

20. Atesok, G.; Somasundaran, P.; Morgan, L.J. Adsorption properties of $\mathrm{Ca}^{2+}$ on Na-kaolinite and its effect on flocculation using polyacrylamides. Colloids Surf. 1988, 32, 127-138. [CrossRef] 
21. De Kretser, R.G.; Scales, P.J.; Boger, D.V. Surface chemistry-rheology inter-relationships in clay suspensions. Colloids Surf. A 1998, 137, 307-318. [CrossRef]

22. Mpofu, P.; Addai-Mensah, J.; Ralston, J. Influence of hydrolyzable metal ions on the interfacial chemistry, particle interactions, and dewatering behavior of kaolinite dispersions. J. Colloid Interface Sci. 2003, 261, 349-359. [CrossRef]

23. Castillo, C.; Ihle, C.F.; Jeldres, R.I. Chemometric optimisation of a copper sulphide tailings flocculation process in the presence of clays. Minerals 2019, 9, 582. [CrossRef]

24. Teh, E.J.; Leong, Y.K.; Liu, Y.; Fourie, A.B.; Fahey, M. Differences in the rheology and surface chemistry of kaolin clay slurries: The source of the variations. Chem. Eng. Sci. 2009, 64, 3817-3825. [CrossRef]

25. Ndlovu, B.; Becker, M.; Forbes, E.; Deglon, D.; Franzidis, J.-P. The influence of phyllosilicate mineralogy on the rheology of mineral slurries. Miner. Eng. 2011, 24, 1314-1322. [CrossRef]

26. Avadiar, L.; Leong, Y.K.; Fourie, A. Physicochemical behaviors of kaolin slurries with and without cations-Contributions of alumina and silica sheets. Colloids Surf. A 2015, 468, 103-113. [CrossRef]

27. Colic, M.; Fisher, M.L.; Franks, G.V. Influence of ion size on short-range repulsive forces between silica surfaces. Langmuir 1998, 14, 6107-6112. [CrossRef]

28. De Kretser, R.; Scales, P.J.; Boger, D.V. Improving clay-based tailings disposal: Case study on coal tailings. AIChE J. 1997, 43, 1894-1903. [CrossRef]

29. Scales, P.J.; Johnson, S.B.; Healy, T.W.; Kapur, P.C. Shear yield stress of partially flocculated colloidal suspensions. AIChE J. 1998, 44, 538-544. [CrossRef]

30. Sofrá, F.; Boger, D.V. Environmental rheology for waste minimisation in the minerals industry. Chem. Eng. J. 2002, 86, 319-330. [CrossRef]

31. Barnes, H.A.; Hutton, J.F.; Walters, K. An Introduction to Rheology. Rheology Series (NL); Elsevier Science: Amsterdam, The Netherlands, 1989.

32. Lin, Y.; Phan-Thien, N.; Lee, J.B.P.; Khoo, B.C. Concentration dependence of yield stress and dynamic moduli of kaolinite suspensions. Langmuir 2015, 31, 4791-4797. [CrossRef]

33. Stickland, A.D.; Kumar, A.; Kusuma, T.E.; Scales, P.J.; Tindley, A.; Biggs, S.; Buscall, R. The effect of premature wall yield on creep testing of strongly flocculated suspensions. Rheol. Acta 2015, 54, 337-352. [CrossRef]

34. Jeldres, R.I.; Toledo, P.G.; Concha, F.; Stickland, A.D.; Usher, S.P.; Scales, P.J. Impact of seawater salts on the viscoelastic behavior of flocculated mineral suspensions. Colloids Surf. A 2014, 461, 295-302. [CrossRef]

35. Oncsik, T.; Trefalt, G.; Borkovec, M.; Szilagyi, I. Specific ion effects on particle aggregation induced by monovalent salts within the Hofmeister series. Langmuir 2015, 31, 3799-3807. [CrossRef] [PubMed]

36. Jeldres, R.I.; Piceros, E.C.; Leiva, W.H.; Toledo, P.G.; Herrera, N. Viscoelasticity and yielding properties of flocculated kaolinite sediments in saline water. Colloids Surf. A 2017, 529, 1009-1015. [CrossRef]

37. Abu-Jdayil, B. Rheology of sodium and calcium bentonite-water dispersions: Effect of electrolytes and aging time. Int. J. Miner. Process. 2011, 98, 208-213. [CrossRef]

38. Li, Y.; Chen, J.; Kang, D.; Guo, J. Depression of pyrite in alkaline medium and its subsequent activation by copper. Miner. Eng. 2012, 26, 64-69. [CrossRef]

39. El-Manharawy, S.; Hafez, A. Study of seawater alkalization as a promising RO pretreatment method. Desalination 2003, 153, 109-120. [CrossRef]

40. Ayoub, G.M.; Zayyat, R.M.; Al-Hindi, M. Precipitation softening: A pretreatment process for seawater desalination. Environ. Sci. Pollut. Res. 2014, 21, 2876-2887. [CrossRef]

41. Kapp, E.M. The precipitation of calcium and magnesium from sea water by sodium hydroxide. Biol. Bull. 1928, 55, 453-458. [CrossRef]

42. Ma, C.; Eggleton, R.A. Cation exchange capacity of kaolinite. Clays Clay Miner. 1999, 47, 174-180.

43. Zhou, Z.; Gunter, W.D. The nature of the surface charge of kaolinite. Clays Clay Miner. 1992, 40, 365-368. [CrossRef]

44. Buscall, R.; Mills, P.D.A.; Stewart, R.F.; Sutton, D.; White, L.R.; Yates, G.E. The rheology of strongly-flocculated suspensions. J. Non-Newtonian Fluid Mech. 1987, 24, 183-202. [CrossRef]

(C) 2019 by the authors. Licensee MDPI, Basel, Switzerland. This article is an open access article distributed under the terms and conditions of the Creative Commons Attribution (CC BY) license (http://creativecommons.org/licenses/by/4.0/). 